\title{
DIFFERENTITION OF POPULATION INCOME AND POVERTY PROBLEM (based on the data of Tyumen region) ${ }^{1}$
}

\author{
A. A. Kouklin, A. G. Leontieva
}

The given article presents the results of analyzing differentiation in cash income of Tyumen region population. The analysis of differentiation has been done with indicators of Foster - Greer - Thorbeek for the territories - members of Tyumen region - KhMAO, YaNAO and South of the region. Social policy conducted in the region during the last decade has been evaluated and set of measures meant to improvement of status of poor population has been suggested.

Transition of Russia to innovative type of development considering consequences of world financial crisis, requires optimal organization of state and regional social protection systems, contributing to lowering the number of poor people, lessening of social differentiation, creation of middle class as a basis for stability and prosperity of the country. The central problem of social-economic policy is the problem of inequality in earnings. High level of property inequalities leads to degradation of the significant part of population, minimizes economic development, creates sensitive areas in the society and interferes with social progress.

It is generally recognized that economic growth is a basis for decrease the number of poor people in the country. According to Rosstat data the cash income growth of population in Russia over the last ten years period stimulated reduction of population size with income less than living wage from 42.3 to $18.5 \mathrm{mln}$. people. (fig. 1) [1].

In Tyumen region specific weight of people with cash income less than regional living wage in general reduced from $21,3 \%$ in 2000 to $9,6 \%$ in 2009 . The most visible reduction of poverty level occurred in the south of the region (table 1) [2].

At the same time, world and domestic experience show that during the economic growth the problem of poverty is becoming more and more urgent in case income increase is accompanied with inequality in their allocation between different population groups.

\footnotetext{
${ }^{1}$ This research was partially financed by special-purpose programme of Ural Branch of Russian Academy of Sciences (UB RAS) supporting interdisciplinary research projects in collaboration with scientists of Siberian and Far East Branches of RAS and integrational project entitled "Socio-economic immunity of the region: diagnostics and prognosis of protectability to crisis phenomenon" (project 09-C-6-1001 "Diagnostics of condition, modelling of tendencies and prognosis of Russia's regions development until 2030").
}

To illustrate the values of inter-regional differentiation of people' income we'll analyze average per capita cash income in different territories of Tyumen region over a period of time from 2000 to 2009 [2].

Table 2 shows the significant difference in income per capita between northern autonomous districts and southern territories of the region in spite of slight reduction in breach value in the studied period. Thus, in 2009 average per capita income in Yamalo-Nenetz autonomous district (38900 rur.) exceed the same income in the south of the region (1752 rur.) more than twice. In 2000 this indicator was 3.3. High earnings in KhMAO and YaNAO are stipulated by branch character of economics in these territories connected with production of fuel and energy resources, where salary is two times higher than the average in the region. Traditionally the lowest level of salary is monitored in agricultural areas of Tyumen region south.

Alongside with inter-territorial, differentiation of income in all regions is enhanced. Thus, in Tyumen region distributing the total scope of cash income between 20\% (quintile) groups, ranked according the growth of cash income, was characterized in 2000-2009 by inequality, tendency to concentrate earnings at certain groups, striking "removing" of middle class and not reducing gap between the rich and the poor. (table 3) [3].

By 2008 the share of the first quintile group of population (with the lowest cash income) on average for the region reduced up to $4.2 \%$. At the same time cash income share in the second, third and forth $20 \%$ groups reduced overall from 45 to $44,4 \%$, that indicates worsening of material welfare in middle class. Insignificant increase of income share appropriated by the first three quintile groups took place in 2009 , though general situation of income distribution was not influenced by that fact.

The share of the fifth quintile group of population (with the highest cash income) comprised during this period of time more than a half of total revenue. The difference between amount of income in the first and fifth groups increased from 11.5 times in 2000 up to 122 times in 2008, comprising in 2009 11.5 times.

Such distribution of income was typical for all areas of the region (figure 2). So, in spite of the fact that the processes of rising mobility are observed 


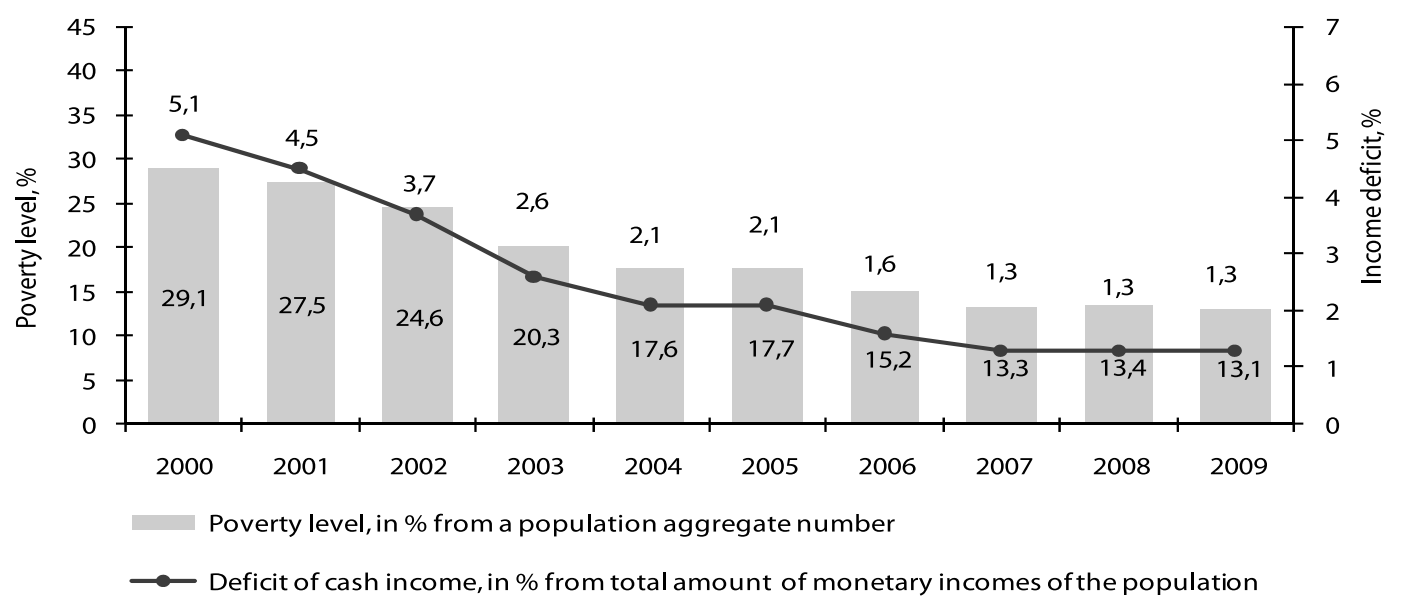

Fig.1. Dynamics of level and depth of poverty in the RF based on macroeconomic data, \%

Table 1

Percentage of population with income less than living wage in total population, $\%$

\begin{tabular}{|c|c|c|c|c|c|c|c|c|c|c|}
\hline & \multicolumn{10}{|c|}{ years } \\
\hline & 2000 & 2001 & 2002 & 2003 & 2004 & 2005 & 2006 & 2007 & 2008 & 2009 \\
\hline $\begin{array}{l}\text { Tyumen region (with } \\
\text { autonomous districts) }\end{array}$ & 21,3 & 15,4 & 15,8 & 12,7 & 12,2 & 11,6 & 11,2 & 10,8 & 10,4 & 9,6 \\
\hline Tyumen region (South) & 29,5 & 27,5 & 24 & 20,5 & 16,5 & 15,3 & 11,7 & 10,8 & 9,5 & 12,2 \\
\hline KhMAO & 11,8 & 9,3 & 11,6 & 10.6 & 10,1 & 7,7 & 7,7 & 7,5 & 7,4 & 8,7 \\
\hline YaNAO & 11,1 & 9,3 & 7,7 & 8,0 & 7,3 & 8,7 & 7,1 & 6,8 & 6,6 & 7,8 \\
\hline \multicolumn{11}{|l|}{ Reference: } \\
\hline $\mathrm{RF}$ & 29,0 & 27,5 & 24,6 & 20,3 & 17,6 & 17,7 & 15,2 & 13,3 & 13,4 & 13,1 \\
\hline
\end{tabular}

Average per capita money incomes of population in different territories of Tyumen region, RUR

Table 2

\begin{tabular}{|l|c|c|c|c|c|c|c|c|c|c|}
\hline & $\mathbf{2 0 0 0}$ & $\mathbf{2 0 0 1}$ & $\mathbf{2 0 0 2}$ & $\mathbf{2 0 0 3}$ & $\mathbf{2 0 0 4}$ & $\mathbf{2 0 0 5}$ & $\mathbf{2 0 0 6}$ & $\mathbf{2 0 0 7}$ & $\mathbf{2 0 0 8}$ & $\mathbf{2 0 0 9}$ \\
\hline $\begin{array}{l}\text { Tyumen region (with } \\
\text { autonomous districts) }\end{array}$ & 4935 & 7109 & 8559 & 10556 & 12191 & 14873 & 18622 & 22519 & 27612 & 27553 \\
\hline Tyumen region (South) & 2267 & 3170 & 4271 & 5906 & 6468 & 8595 & 11118 & 13642 & 17336 & 17522 \\
\hline KhMAO & 6628 & 9594 & 10846 & 12892 & 14972 & 18009 & 22380 & 27110 & 32872 & 32263 \\
\hline YaNAO & 7563 & 10733 & 13298 & 15962 & 18868 & 21766 & 27081 & 31512 & 38133 & 38900 \\
\hline Reference: & \multicolumn{7}{|l|}{} \\
\hline RF & 2281 & 3062 & 3947 & 5170 & 6410 & 8112 & 10196 & 12603 & 14939 & 16886 \\
\hline
\end{tabular}

Table 3

Distributing the total scope of population cash income in Tyumen region (including autonomous districts) in 2000-2009 (\%)

\begin{tabular}{|l|c|c|c|c|c|c|c|c|c|c|}
\hline & $\mathbf{2 0 0 0}$ & $\mathbf{2 0 0 1}$ & $\mathbf{2 0 0 2}$ & $\mathbf{2 0 0 3}$ & $\mathbf{2 0 0 4}$ & $\mathbf{2 0 0 5}$ & $\mathbf{2 0 0 6}$ & $\mathbf{2 0 0 7}$ & $\mathbf{2 0 0 8}$ & $\mathbf{2 0 0 9}$ \\
\hline Cash income- total & 100 & 100 & 100 & 100 & 100 & 100 & 100 & 100 & 100 & 100 \\
\hline $\begin{array}{l}\text { Including 20\% groups } \\
\text { of population: }\end{array}$ & & & & & & & & & & \\
\hline $\begin{array}{l}\text { first (with the lowest } \\
\text { income) }\end{array}$ & 4,4 & 4,6 & 4,5 & 4,5 & 4,5 & 4,4 & 4,4 & 4,3 & 4,2 & 4,4 \\
\hline second & 8,9 & 9,2 & 9,0 & 9,0 & 9,0 & 8,9 & 8,8 & 8,7 & 8,7 & 8,9 \\
\hline third & 14,0 & 14,2 & 14,1 & 14,1 & 14,1 & 14,0 & 13,9 & 13,8 & 13,7 & 13,9 \\
\hline forth & 22,1 & 22,2 & 22,2 & 22,2 & 22,2 & 22,1 & 22,0 & 22,0 & 22,0 & 22,1 \\
\hline $\begin{array}{l}\text { fifth (with the highest } \\
\text { income) }\end{array}$ & 50,6 & 49,8 & 50,2 & 50,2 & 50,2 & 50,6 & 50,9 & 51,2 & 51,4 & 50,7 \\
\hline
\end{tabular}




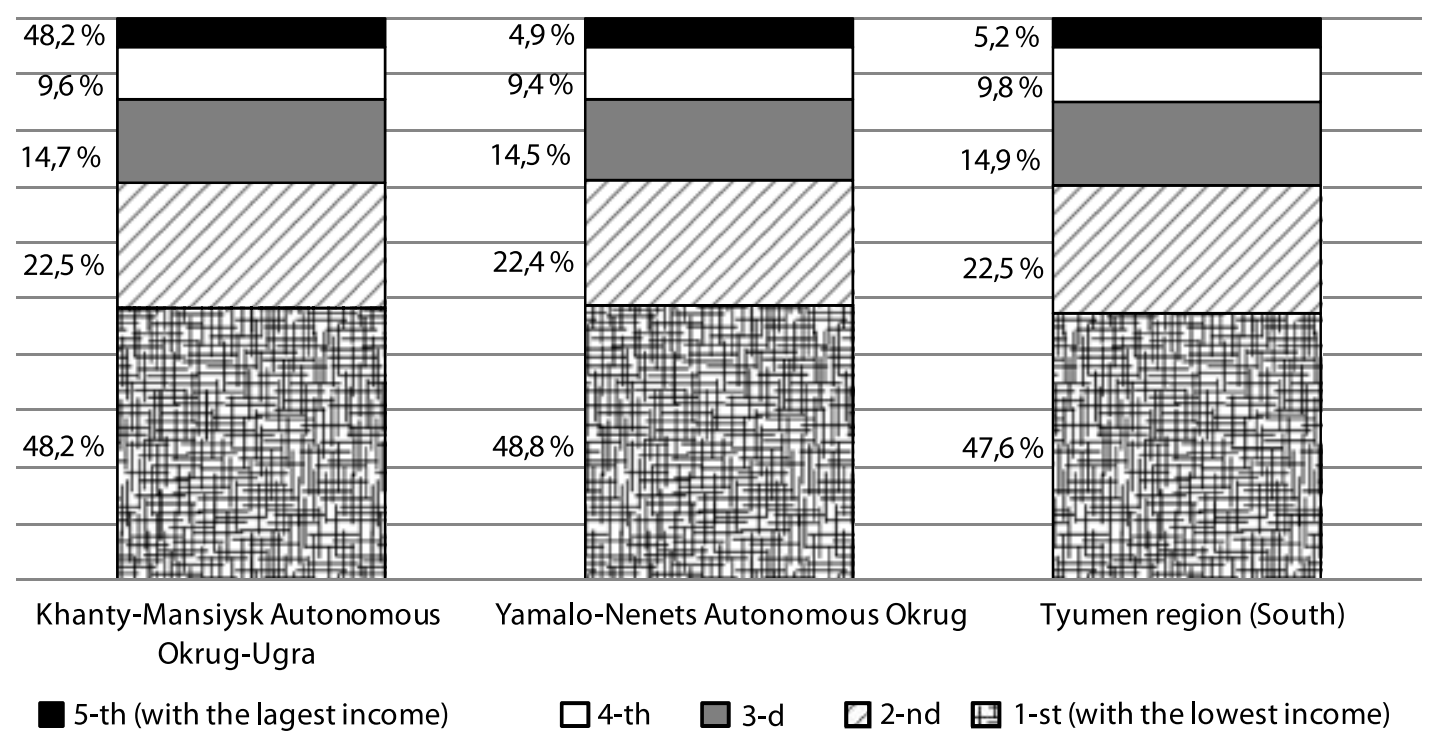

Fig. 2. Cash income according to 20-\% groups of population in the areas of Tyumen region in 2009

in material differentiation, they are not of general character, located mainly in groups of population with average income. The upper group still concentrates a significant part of public wealth preserving the gap between it and other social layers.

General level of inequality in incomes reflects Gini coefficient values (index of revenue concentration) and decimal coefficient ( funds coefficient). In 2009 index of revenue concentration for the population of the region (Gini coefficient), describing degree of violation for the real volume of income distribution from its regular distribution comprised 0,456 that is higher than All-Russian indicator $(0,422)$. In Khanty-Mansiysk Autonomous OkrugUgra Gini coefficient was 0,427; in Yamalo-Nenets Autonomous Okrug $-0,4343$, in the south of the region it was 0,419. Comparing Gini coefficient value with the previous year it lowered per $2 \%$ [4]. General lowering of the coefficient testifies to partial leveling of inequality in distribution of total revenue in society.

Inequality growth in distribution of population according to per capita revenue is affirmed by funds coefficient. Dynamics of funds coefficient in the given period was ambiguous (fig. 3). In the whole this coefficient was rather high. The lowest values of inequality indicators in revenue distribution were in 2000-2001. Further they began to grow and beginning with 2006 - they began to stabilize. This means that tendency of differentiation according to revenue still exists.

So, in spite of positive dynamics for average per capita cash income, social polarization in the region remains on the high level, this puts the brakes on solving poverty problems and unacceptable inequality level. Modern scientific investigations of poverty significantly extended approaches to defining and measuring of this social-economic phe-

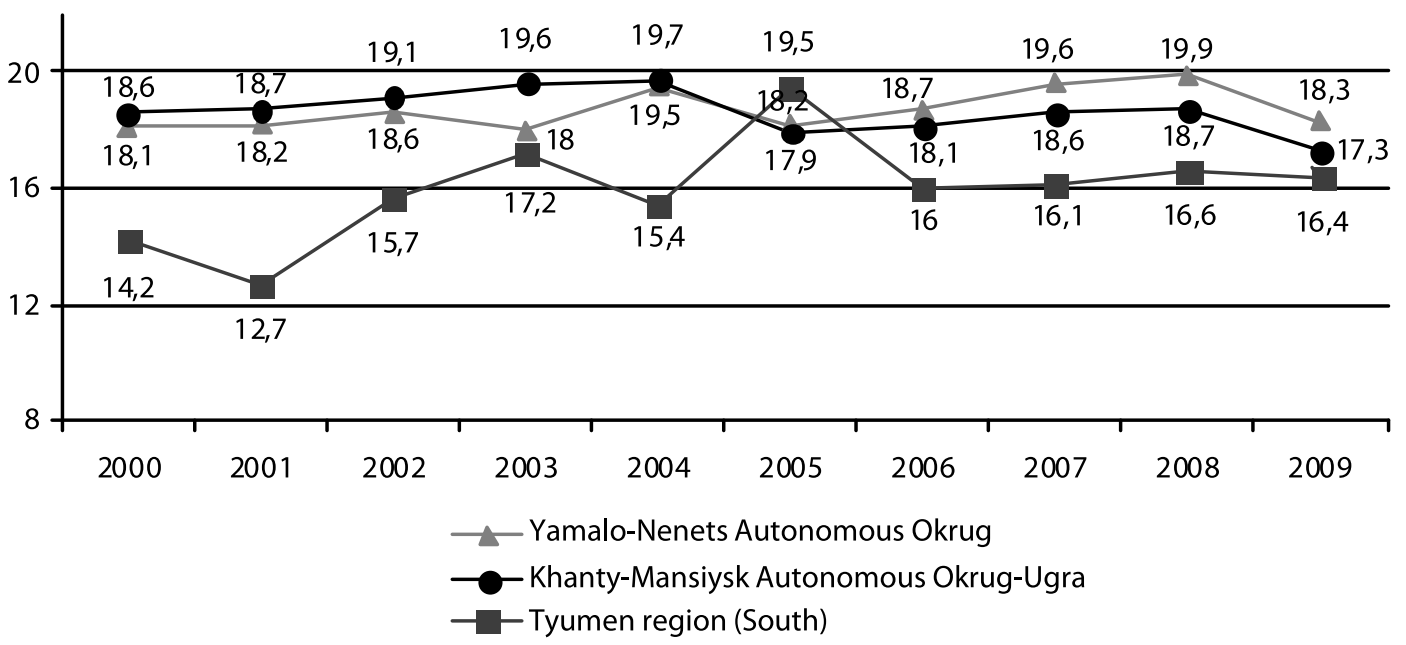

Fig. 3. Funds coefficient in the territories of Tyumen region in 2000-2009, times 
nomenon. In practice special indicators FosterGreer-Thorbecke: index of poverty number, index of poverty deficit $P_{1}$, index of quadratic poverty deficit $P_{2}$, and also Sen index (Sen A. K., 1995) were used to measure poverty of society and poverty of the poor. The necessity to study poverty indictors using the system of the mentioned indices is explained by shortcomings of separate indices. Thus, index of poor people specific weight $\left(P_{0}\right)$ doesn't take into account degree and acuteness of this phenomenon. People with significant differences in income, being though beyond the poverty level are equalized in $P_{0}$ index.

Poverty index $P_{1}$ Foster-Greer-Thorbecke takes into account data of how low beyond the poverty level are people revenues, so this index defines poverty depth. Index of poverty acuteness $\left(P_{2}\right)$ is calculated as root-mean-square value of relative poverty deficit. With this index poverty depth is measured, that gives more attention to the poorest layers of population. In other words, root-mean-square value of poverty depth takes into account inequality among the poor. Index $P_{2}$ is more useful, than simply specific weight of population number with revenues beyond the poverty level, for comparison measures aimed at improvement situation for disadvantaged population in the course of time. Thus indices of poverty depth and acuteness are rather important additional indicators illustrating poverty differentiation.

Common formula for indicators of this class depends on the value of parameter $a$, which is equal to 0 - for population beyond the poverty level, 1 - for poverty depth and 2 - for poverty acuteness, in the following formula:

$$
P_{a}=\frac{1}{n} \sum_{i=1}^{q}\left[\frac{z-y_{i}}{z}\right]^{a}
$$

where $y_{i}$ - income of $i$-person, beyond the poverty level, $z$ - poverty level.

Table 3 presents values of indices $P_{1}$ and $P_{2}$ and Sen index. These indices have been found using method of simple interpolation. Methods of calculating coefficients has been suggested by professor Kakwani (Kakwani, 1990) [5]. Indicators of revenue inequality for different territories of Tyumen region in 2000-2009 are given in table 4.

Analysis of the values of these coefficients allows to define directivity of social policy in the region serving to reduce poor population. Thus, the most significant reduction of poverty index comparing to other indices indicates that government took measures for growth of wellbeing not for a separate group of people but aimed at creating conditions for the growth of total revenues in the country. Improvement macroeconomic situation in the country and creation of additional working places, increasing people income, reduces first of all the number of "nearly poor" people, i. e. people with income insignificantly being above the poverty level. In case the root-mean-square value of poverty deficit reduces quicker, it means that the government provides selective assistance with the help of transfers and tries to reduce the poorest group of people. Fast reduction of poverty deficit shows that the government takes care of all the groups of poor people.

In $200913 \%$ of the poor were at the abject poverty level, the share of the poor was $12.2 \%$ from the total number of population. Indictor $P_{2}$ was 0.021 , i. e. $2.1 \%$ of the poor had income approximately

Table 4

Indicators of revenue inequality for different territories of Tyumen region

\begin{tabular}{|c|c|c|c|c|c|c|c|c|c|c|c|}
\hline \multirow{2}{*}{ indicator } & \multicolumn{11}{|c|}{ years } \\
\hline & 2000 & 2001 & 2002 & 2003 & 2004 & 2005 & 2006 & 2007 & 2008 & 2009 & $2010^{*}$ \\
\hline \multicolumn{12}{|c|}{ Tyumen region (South) } \\
\hline Sen index & 0,223 & 0,170 & 0,177 & 0,143 & 0,137 & 0,160 & 0,165 & 0,160 & 0,130 & 0,132 & 0,126 \\
\hline$P_{1}$ & 0,243 & 0,210 & 0,197 & 0,198 & 0,176 & 0,144 & 0,148 & 0,157 & 0,130 & 0,110 & 0,10 \\
\hline$P_{2}$ & 0,124 & 0,110 & 0,115 & 0,110 & 0,074 & 0,057 & 0,072 & 0,024 & 0,032 & 0,021 & 0,009 \\
\hline \multicolumn{12}{|c|}{ Khanty-Mansiysk Autonomous Okrug (KhMAO) } \\
\hline Sen index & 0,120 & 0,103 & 0,109 & 0,097 & 0,089 & 0,081 & 0,079 & 0,071 & 0,068 & 0,085 & 0,063 \\
\hline$P_{1}$ & 0,118 & 0,093 & 0,116 & 0,106 & 0,101 & 0,078 & 0,077 & 0,075 & 0,074 & 0,087 & 0,068 \\
\hline$P_{2}$ & 0,014 & 0,009 & 0,014 & 0,012 & 0,011 & 0,006 & 0,006 & 0,006 & 0,006 & 0,008 & 0,004 \\
\hline \multicolumn{12}{|c|}{ Yamalo-Nenets Autonomous Okrug (YaNAO) } \\
\hline Sen index & 0,120 & 0,102 & 0,081 & 0,083 & 0,08 & 0,085 & 0,069 & 0,067 & 0,065 & 0,080 & 0,120 \\
\hline$P_{1}$ & 0,111 & 0,093 & 0,077 & 0,080 & 0,072 & 0,087 & 0,0708 & 0,068 & 0,066 & 0,078 & 0,062 \\
\hline$P_{2}$ & 0,012 & 0,009 & 0,006 & 0,006 & 0,005 & 0,008 & 0,005 & 0,005 & 0,004 & 0,006 & 0,004 \\
\hline
\end{tabular}

- calculation based on prognosis 
equal to a quarter of living wage ad belonged to the category of poor people. Income of an average poor person in Tyumen region south was approximately $11 \%$ beyond the poverty level, that is, poverty in the region is not deep.

In the northern autonomous districts the share of the poor in total population was $8.7 \%$ in KhMAO and $7.8 \%$ in YaNAO, and at the abject poverty level were 8.5 and $8 \%$ accordingly. The share of the poor in the northern territories is insignificant $(0.6-$ $0.7 \%$ ). Poverty depth in autonomous districts is also less than in the south of the region.

The root-mean-square value of poverty deficit was reduced at the highest rate. In 2000-2009 in the south of the region it was reduced more than $80 \%$, in KhMAO - 43\%, in YaNAO - 67\%. Lower rates of reduction showed index of poverty deficit. So, evaluating dynamics of estimate indicators one can conclude that during 2000-2009 the policy conducted at the territory of the whole Tyumen region was directed on the reduction of the poorest population number. But increase of social grants to this group of population at the expense of social benefits doesn't allow to solve the problem of poverty fundamentally because on the one hand, such measures don't influence inequality and relative poverty properly, on the other hand, they may be the reason of inflation increase and at last they don't eliminate reasons for reproduction relative poverty and don't reduce its scale.

Active policy of social protection should be conducted more intensively. New additional stimulating measures are necessary that will increase "self-supporting" benefits of a family. And some positive experience has been accumulateB in the region. Thus, in the south of the region the government has lately conducted not only passive policy protecting socially vulnerable people by paying social allowances that increase revenue of low-income families up to the regional living-wage but active policy as well. It is directed to creation of new facilities for processing agricultural products, to render support to low-income families for development personal subsidiary plots, family, private enterprises using budget funds, so the regional government created conditions helping to increase living standards for all population of the region.
Improvement of situation with the poor may take place as a result of complex social policy aimed at reduction of income inequality by elimination of deformations in distribution and bring distribution mechanisms into accord with world standards. The major part of working people' income is salary at a principal working place, additional job, subsidies and benefits are of less importance. Therefore, state measures aimed at poverty reduction should be directed first of all on radical reforming of salary. But these measures don't reduce level of income inequality in the regions. That's why regional authorities have to pay much attention to fulfilling programs that go beyond the narrow definition of social protection, in particular, programs for increase effectiveness of labour market, quality of labour force and education, etc. Besides, efficient policy in health care, environment protection, development of proper living conditions will stipulate decrease in society social polarization.

In conclusion it is necessary to mention that in the process of working out regional programs aimed at poverty reduction and increase of population' living conditions, it is extremely important to analyze situation from the point of view of social-economic inequality and to choose measures that are aimed at reduction of parasitical attitude of mind among ablebodied citizens, increase of human potential quality and also providing conditions for their realization.

\section{References}

1. Russia in figures - 2010 // Federal service of governmental statistics [electronic resource]. Access - www.gks.ru

2. Social status and living standards of Russian population. 2010: statistical collection of data // Federal service of governmental statistics [electronic resource]. Access - www.gks.ru

3. Social-economic poverty indicators/statistical newsletter- 2009 // Federal service of governmental statistics [electronic resource]. Access- www.gks.ru

4. Regional body for Federal government statistics service in Tyumen region. [electronic resource]. Access - www.tumstat.gks.ru

5. Foster J., Greer J., Thorbecke E. A class of decomposable Poverty Measures, Econometrika 52 (3), 761-766.

\section{УДК: 316. 344.233 (571.12)}

keywords: poverty level, social-economic differentiation, funds coefficient, Gini index, number of the poor index, poverty acuteness, poverty depth, social protection, passive and active policy of social protection 


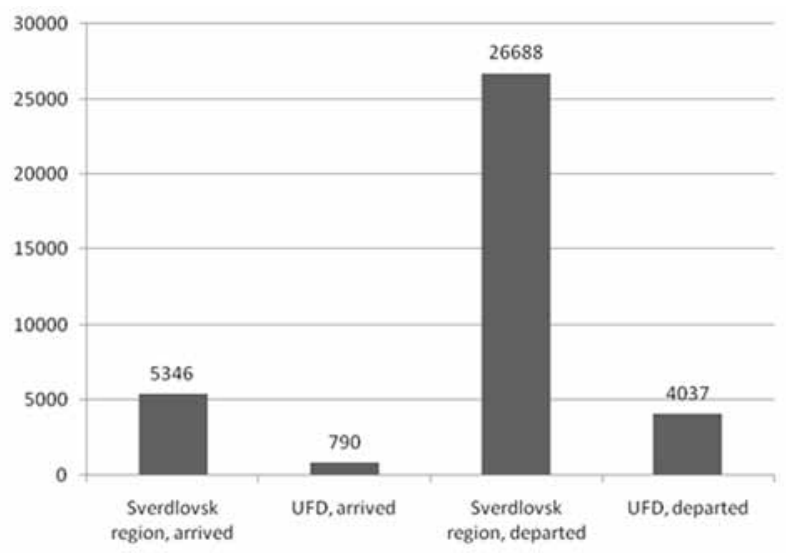

Pic. 1. Relation between migration in Sverdlovsk region and UFD during the year of 2009. The official data of FSSS

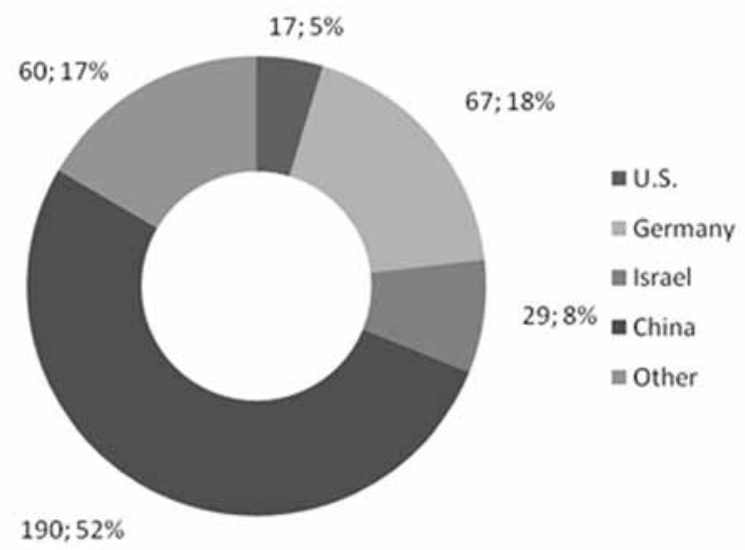

Pic. 2. Distribution of migrants arrived in the year of 2009 at the territory of Sverdlovsk region from the foreign countries (excluding the ex-USSR republics)

firstly by the presence of numerous high-tech enterprises at its territory. Operation of these enterprises is impossible without availability of specialists of high qualification working at the international level [9].

The principal foreign trade partners of Sverdlovsk region are the USA, the Netherlands, Germany, India, China, Kazakhstan. The investment attractiveness of Sverdlovsk region is favored by organization of the traditional International arms exhibition in the city of Nizhny Tagil, the annual Russian economical forum in the city of Ekaterinburg, various festivals and tournaments of the Russian and international scales [2]. Based on the foregoing, one can conclude that Sverdlovsk region is very attractive not only from the investment point of view, but also for migrants. The region had established migration relations with the foreign partners. During the year of 2009 the 5346 persons arrived at the territory of Sverdlovsk region, among them the 4984 persons arrived from the ex-USSR republics and 362 persons arrived from the other foreign countries. For the year of 2010 the maximum quota for labour migrants in Sverdlovsk region was 100693 persons [10].
According to the official statistics during the year of 2009 the following number of persons arrived from the foreign countries (excluding the ex-USSR republics): Afghanistan - 1, Australia - 5, Belgium 1, Bulgaria - 4, Cameroon - 1, Canada - 6, China - 190, Czech Republic - 2, Finland - 1, France -1 , Germany -67 , India -1 , Iran -1 , Israel 29, Italy -4 , Lebanon -2 , Poland -2 , Portugal - 1, Saudi Arabia - 1, Slovakia - 1, Vietnam - 7, Spain - 2, Switzerland - 1, Syria - 3, United Arab Emirates - 2, Turkey - 3, Egypt - 2, Great Britain -4 , USA -17 . The number of immigrants arrived to Sverdlovsk region in the year of 2009 from the foreign countries, excluding ex-USSR republics, increased in comparison with the year of 2008 by $19 \%$ (291 and 362 persons, respectively). Among them the greatest number of people arrived from China, Germany, Israel, and USA [6]. As a rule these persons have high qualification with corresponding salary. They do not violate the migration legislation. At present the proportion of the hi-tech industries in Sverdlovsk region exceeds the average Russian level by $3 \%$ and about 4 thousand of people work in the industrial parks [10].

From the abovementioned data it is possible to make the conclusion that with decreasing the influence of the world economical crisis the migration processes in Sverdlovsk region can restore to the pre-crisis level and the dynamics of migration will improve with each year. Within the nearest future, probably, the number of migrants from such countries, as China, Germany, Israel, and USA, in total, may overcome the number of migrants from the ex-USSR republics. One can expect that the list of abovementioned countries may include also Italy, Canada, Bulgaria, and Austria. In spite of the world economical crisis, during the year of 2009, the level of international migration to Sverdlovsk region increased by $19 \%$. This fact confirms the high migration attractiveness of the region. Due to the increased volume of the influx of migrants in the receiving society [5], all the more urgent becomes the problem of determining the migration potential of the region $[7,8]$. One must agree with the fact that in the region «UFD» will be intensively to forge new immigration system.

\section{References}

1. Site Demoscope [electronic resource]. URL: demoscope. ru № 393-394 12-25 October 2009

2. Alexander Misharin. Development of industrial parks - a key challenge towards a "smart economy" / / Web site of the Government of Sverdlovsk Region [electronic resource]. URL: http://www.midural.ru/news/100046/document6935

3. Alferov, E. J., Golikov, S. V., Yepanchintsev S. P., Kornilov G. E., Kuzmin A. I., Orudzhieva A. G. Ethnodemografical 
development of the Urals in the 19-20 centuries. Ekaterinburg 2000. 104 pp.

4. Population policies in the region: problems and prospects / [text]: sb. st. Under. Ed. Doctor of Sociology, prof. A. Kuzmin / Institute of Economics, UB RAS, 2010. 196.

5. Dmitriev A. V., Poduhov G. A. The receiving society: the practice of interaction with immigrants. // Sotsis. 2009. (№ 10)

6. Debt Victor. Have exhausted the quota // Rossiyskaya Gazeta. 2009. December 17 (№ 5066).

7. Rybakovsky L. L. Migration potential. Concept and criteria of evaluation. // Sotsis. 2009. (№ 2)
8. Rybakovsky L. L. Comparative evaluation of a demographic crisis of Russian regions // Sotsis. 2008. (№ 10)

9. Site Goskomstat of Russia [electronic resource]. URL: http://www.gks.ru.

10. Sverdlovsk Oblast Duma website [electronic resource]. URL: http://www.duma.midural.ru.

U.D.C. 314.143 (1)

keywords: migration, population, migration gain, migration dynamics, migration links

\section{РАЗВИТИЕ ПРЕДПРИНИМАТЕЛЬСКИХ СЕТЕЙ В СФЕРЕ ЖИЛИЩНО-КОММУНАЛЬНОГО ХОЗЯЙСТВА В РЕГИОНАХ}

\section{Г. И. Лисин}

В данной статье изложены основные проблемы в сфере жмилищно-коммунального хозяйства в регионах, приведены меры по их решению и созданию благоприятных условий для формирования предпринимательских сетей. Определен комплекс мероприятий, направленных на развитие предпринимательских сетей в конкурентной среде. Сформулирована концепция развития данной отрасли экономики.

Жилищно-коммунальное хозяйство является одной из самых прибыльных отраслей экономики во многих развитых странах. С одной стороны, в данном секторе экономики вращаются крупные суммы - это и деньги, которые население платит за услуги жилищно-коммунального хозяйства, и субсидии государства. Кроме того, существует постоянный спрос на услуги компаний, осуществляющих жилищнокоммунальное обслуживание. Неслучайно в этой отрасли работают транснациональные компании, такие как Suez или American Water Works [3, c. 31-35]. С другой стороны, система жилищно-коммунального хозяйства представляет собой устаревшие технологии и оборудование, затратную систему производства и транспортировки тепла и воды. Финансовое обеспечение содержания городского хозяйства в его нынешнем виде непосильно как для

\footnotetext{
${ }^{1}$ Статья подготовлена при поддержке гранта РГНФ № 1002-00294а «Оценка влияния малого предпринимательства на социально-экономическое развитие узкоспециализированных территорий в условиях кризиса».
}

потребителей жилищно-коммунальных услуг, так и для муниципальных образований $[1,2]$. При всей внешней привлекательности отрасли ни российские, ни зарубежные предпринимательские сети не спешат инвестировать в ЖКХ. Существует целый ряд причин, объясняющих такую «осторожность» со стороны бизнеса.

1. Экономические причины, заключаются в том, что у жилищно-коммунального хозяйства нет собственных средств на развитие, а кредиты недоступны. Во-первых, потому что дороги, во-вторых, потому что у большинства муниципалитетов нет под эти кредиты обеспечения. Остается лишь привлечение в отрасль компаний-инвесторов, с передачей жилищнокоммунального хозяйства в собственность или в аренду этим компаниям. Как показала практика, в России такими инвесторами являются лишь сырьевые или энергетические монополисты.

2. Социальные проблемы заключаются в том, что население постоянно сталкивается с услугами жилищно-коммунального хозяйства и любой сбой в их работе приводит к нервозности в обществе. К примеру, произошла авария на теплотрассе в декабре, коммунальные службы вынуждены отключить отопление, и целые районы остаются без тепла, при этом ответственность на себя брать никто не хочет - ни органы местного самоуправления, ни управляющая компания. Кроме того, серьезной социальной проблемой является постоянный рост тарифов на услуги жилищно-коммунального хозяйства. 